\title{
Szemle
}

FAZEKAS ÉVA*

\section{A nem vagyoni kártérítés és rehabilitáció jogi szabályozása és gyakorlati érvényesülése Angliában}

\author{
common law - kártérítés - nem vagyoni kártérítés - személyi sérülés - \\ rehabilitáció
}

Az angolszász jogrendszer sajátosságai, a kontinentális jogtól való alapvető eltérései közismertnek tekinthetők. Ez a tanulmány a nem vagyoni kártérítés szabályait, gyakorlatát mutatja be, mégpedig úgy, hogy a biztosítás és a rehabilitáció intézményeit is hozzákapcsolja. Ezek sajátosságaira fókuszál, s a tárgykör szempontjából meghatározó ítéletek alapján mutatja be gyakorlati érvényesülésüket.

\section{Az angolszász kártérítési jog sajátosságai}

Az angolszász kártérítési jog központi eleme a vétkesség. A vétkesség fogalma viszonylag új keletű az angolszász jogrendszerben, csak a 19. század végén, 20. század elején kezdték el használni. A vétkesség megállapításához a károsultnak először is bizonyítania kell a gondossági kötelezettség (duty of care) megszegését. A gondossági kötelezettség koncepciója a Donoghue v. Stevenson ${ }^{1}$ ügyben született ítélet után vált általánossá, mikor is a Lordok Háza elutasította a korábbi

* Dr. Fazekas Éva Dóra abszolutóriumot szerzett PhD-hallgató, Debreceni Egyetem, Marton Géza Állam- és Jogtudományi Doktori Iskola; ágazatvezető, Allianz Hungária Biztosító Zrt., fazeka01@gmail.com.

1 (1932) AC 562. Az ügyet úgy is szokták emelgetni, mint a „csiga az üvegben ügy”, melyben a károsult egy barátja által vásárolt üveg gyömbérsör elfogyasztása után látta csak, hogy az üveg alján egy félig elrohadt csiga teteme volt. A későbbi orvosi vizsgálat megállapította, hogy a károsult gyomorhurutot kapott, aki ezután pert indított a gyömbérsör gyártója ellen, mely per során az ügyvédei azzal érveltek, hogy a gyártó megszegte a „duty of care” kötelezettségét. 
rendelkezéseket, melyek szerint a gondatlanságért való felelősség csak bizonyos, meghatározott esetekben került kimondásra, és megalapozta az általános kötelezettséget: „megfelelö gondosságot kell tanúsítani, hogy elkerülhető legyen minden olyan cselekedet vagy mulasztás, amely megfelelő elörelátás tanúsítása mellett valószínüsíthetöleg megsértené a másik felet”. Ahogy egy másik esetben ${ }^{2}$ kimondta a bíróság, a gondossági kötelezettség akkor kerül megsértésre, ha a károsult bizonyítani tudja, hogy az elszenvedett károsodás elöre látható volt, a károkozó és közte kapcsolat volt, és hogy az egyéb körülmények alapján is fair, jogos és méltányos a károkozót felelössé tenni.

Az egyéb körülmények vizsgálatát a perben eljáró bíróság a „hármas teszt” alkalmazásával egészítette ki. Először is a gondossági kötelezettség megszegése akkor jön szóba, ha a károsodás - mely az okozó magatartásának következménye - elöre látható (ez a már hivatkozott Donoghue v. Stevenson ügyben került kimondásra). Másodszor irányadó a felek közötti kapcsolat közelsége, harmadszor pedig a kártérítési kötelezettség meg kell, hogy feleljen az észszerüség, igazságosság és méltányosság követelményének. A gondossági kötelezettség megsértésének hiánya azt jelenti, hogy még abban az esetben sem tehető felelőssé a károkozó, ha vétkes volt, és ezzel kárt okozott. Ha azonban a károsult bizonyítani tudja, hogy a károkozó gondossági kötelezettséggel tartozott irányában, akkor már csak azt kell bizonyítania, hogy azt meg is sértette, tehát vétkes volt.

A duty of care jelentőségét az adja, hogy - míg a kontinentális jogban általában jogszabályban rögzítik a jog által védett értékeket, és a bírák ezekhez igazodva döntenek kártérítési ügyekben - az angol jogban a gondossági kötelezettség megsértésének bizonyítási kötelezettsége áll a kártérítés megállapításának középpontjában.

A vétkesség meghatározása két lépcsőből álló folyamat. Először is a bíróságnak meg kell határoznia a gondosság mértékét, mellyel a károkozó a károsultnak tartozott. Ennek általános mértéke az a gondosság, mely általában elvárható a kérdéses cselekedet gyakorlásakor. Ennek meghatározásakor a bíróságok általában tekintetbe veszik az elöreláthatóságot, a károsodás veszélyét, a károsodás elkerüléséhez szükséges költségeket, és azt a társadalomra gyakorolt kedvező hatást, melyet a cselekvés hiánya okozhat. ${ }^{3}$

A következő lépés, hogy a károsult bizonyítsa, hogy a károkozó magatartása okozta a kárát. Ezt az úgynevezett „but-for” teszttel lehet bizonyítani: ha nincs a károkozó magatartása, akkor is bekövetkezett volna-e a károsult kára? Ha a válasz nem, akkor az oksági teszt eredménye pozitív. Ha a válasz igen, akkor a károkozó nem tehető felelőssé, még akkor sem, ha vétkessége megállapítható.

Ha az oksági teszt megáll, akkor a károsultnak azt kell bizonyítania, hogy az elszenvedett kár és a károkozói magatartás között összefüggés áll fennt. A károkozó akkor sem tehető felelőssé, ha nem láthatta elöre magatartása következményeit.

2 Caparo v. Dickman (1990) 2 AC 605. Az ügyben a Caparo Industries PLC fel akarta vásárolni a Fidelity PLC, melynek könyvelője volt Dickman. A Fidelity vállalat részvényei folyamatosan estek, és miután a felvásárlás megtörtént, derült ki, hogy a könyvek szerint a felvásárolt vállalat még a közöltnél is rosszabb helyzetben van. A Caparo pert indított Dickman ellen.

3 Deakin, Johnson-MarkesinIs Basil: Markesinis and Deakin's Tort Law. Oxford Univerity Press, Oxford 2003, 80. 
Ha a károsult mindezeket bizonyítani tudja, akkor teljes kártérítésre jogosult, vagyis olyan helyzetbe kell hozni, mintha a károsodás meg sem történt volna. A károsult igényt tarthat vagyoni kárai, úgymint a keresetkiesés, gyógyászati költségek, tulajdonban esett károk, egyéb felmerült költségek, valamint nem vagyoni kárai - fájdalom és a kellemetlenségek - pénzbeli értékére. Amennyiben a sérülés még a bírósági eljárás után is fennáll, illetve folytatódik, a bírónak ezt a körülményt is figyelembe kell vennie az ítélethozatalkor, mivel a károkat nem lehet újra értékelni később. Ahogy Lord Scarman mondta a Lim v. Camden \& Islington Health Authority esetben:4 "csak egy dolog biztos, az idő majd bebizonyítja, hogy a kártérítés vagy túl magas, vagy túl alacsony volt".

A bíróságnak azonban meghatározott esetekben lehetősége van úgynevezett átmeneti kártérítést (provisional damage) is megállapítani. Az átmeneti kártérítést 1981-ben vezették be, és akkor lehet megítélni, ha a károsult állapota előre láthatólag súlyosan romlani fog, vagy a jövőben más súlyos betegség alakul ki nála a baleset következtében. A Hurditch $v$. Sheffield Health Authority ügyben ${ }^{5}$ a bíróság megállapította, hogy az eljáró bíróság meghatározhatja azt az időt, amelyen belül a károsult további igénnyel élhet, ha rosszabbodik az állapota. A Willson v. Ministry of Defence ügyben ${ }^{6}$ továbbá azt is feltételül szabta a bíróság, hogy az állapotroszszabbodás valódi és súlyos esélye fenn kell, hogy álljon ahhoz, hogy az átmeneti kártérítés megítélhető legyen.

A következő jogcímeken lehet kártérítéssel élni:

- általános károk: ez magában foglalja az elmúlt, jelenlegi és jövőbeni fájdalmat és szenvedést (pain and suffering), melyet a károsodás okozott, beleértve a pszichológiai jellegü károkat is, és azon kellemetlenségeket, melyek magában foglalják az élet élvezetének elveszítését (loss of amenity),

- vagyoni károk és költségek,

- tulajdonban esett károk,

- harmadik fél által elszenvedett károk, például munkáltató vagy rokonok balesettel kapcsolatos kárai és költségei,

- jövőbeni károk, úgymint jövőbeni keresetveszteség, gyógyászati és egyéb költségek. $^{7}$

4 (1980) AC 174. Az ügyben a károsultat (aki maga is orvos) egy rutinműtétet követően (még a lábadozórészlegben) hirtelen szívmegállás és annak következtében agykárosodás érte, ami miatt képtelené vált ellátni önmagát. A károsodásért az egészségügyi intézmény felelős dolgozója volt okolható. A bíróság nem vagyoni kártérítésként (egyéb vagyoni tételek mellett) £20.000 összeget állapított meg.

5 (1989) 2 ALL ER 869. A károsult azbesztnek való kitettség következtében keletkezett egészségkárosodás miatt követelt kártérítést. Mivel a felek nem tudtak megállapodni a károsult egészségi állapotának prognózisában, így a bíróság átmeneti kártérítést állapított meg.

6 (1991) 1 ALL ER 638. Az ügyben a bíróság azzal utasította el a károsult átmeneti kártérítési igényét, hogy a bokaízületi gyulladásából eredő egészségkárosodás jövőbeli alakulását nem lehet teljes biztonsággal elörevetíteni.

7 Neocleus, Martha Warren: Personal Injury - Practice and Procedure in Europe. Cavendish Publishing, London, 1997, 29. 


\section{Nem vagyoni károk az angol jogban}

Az angol jog sajátossága, hogy negatív megközelítéssel határozza meg az általános károk (nem vagyoni károk) fogalmát. Lényegileg tehát a nem vagyoni károk fogalmába tartozik minden olyan hátrány, amely a vagyoni károk körén kívül esik. A vagyoni károkat ellenben meghatározza az angol jog, eszerint vagyoni kárnak minősül mindaz a kár, amely egy személyt vagyonában ér, pénzben kifejezhető, illetve idetartoznak az ingó és ingatlan dolgokban, illetve immateriális javakban pl. értékpapírok - okozott károk. Minden más bizonyítható hátrány a nem vagyoni károk körébe esik. Nem szükséges tehát olyan elismert személyiségi jog, melynek megsértése maga után vonhatná a kártérítés megállapítását, nincs felsorolása azon jogvédett érdekeknek, melyek megsértése esetén nem vagyoni kártérítést lehetne igényelni. A károsultnak azt kell bizonyítania, hogy a vagyoni hátrányok körén kívül eső hátrány érte a károkozó magatartással összefüggésben. Így a bíróságok számára nagy a mozgástér, illetve a szabad mérlegelés lehetősége.

A károkozó védekezhet azzal, hogy a károsult is vétkes volt, és vétkessége hozzájárult a károsodás bekövetkeztéhez - például gépjármübalesetek esetén az utasnak nem volt bekötve a biztonsági öve -, ebben az esetben a bíróság közrehatást állapíthat meg a károsult részéről, és ennek figyelembevételével állapítja meg a kártérítési összeget.

Az angol kártérítési jog különleges eleme az exemplary damages kategóriája. Ez egy olyan büntető kártérítési fajta, mely meghatározott, súlyosan elítélendő esetekben a károkozó megbüntetésére szolgál az általa elkövetett káresemény előidézéséért. A károsult pedig azért a mentális aggodalomért kapja a többletkártérítést, amelyet a fenti súlyosan elítélendő káresemény során kellett átélnie.

$\mathrm{Az}$ angol kártérítési jog külön jogcímként ismeri el a loss of congenial employment-et, azaz ha a károsult sérülése eredményeként elveszíti annak lehetőségét, hogy olyan munkát végezzen, mely számára megfelelő és kielégítő. Ahogy azt a Hale v. London Underground esetben ${ }^{8}$ kifejtette a bíróság, nem kell, hogy ez a foglalkozás különleges legyen, inkább szubjektíven kell azt vizsgálni, hogy a károsult az adott foglalkozásban mennyire tudta magát kiteljesíteni, és mennyire köteleződött el irányában. Ebben az esetben egy tüzoltó sérült meg olyan mértékben, hogy a továbbiakban csak irodai munkát tudott elvégezni, és a kártérítéshez alapot szolgáltatott az, hogy a káresemény következtében nem tudta a továbbiakban a tüzoltási és mentési munkákat elvégezni.

\subsection{A nem vagyoni kártérités bírói gyakorlata Angliában}

A nem vagyoni kártérítés mértékét a gyakorlatban a Fellebbviteli Bíróság által időröl időre kibocsátott irányelvek szabják meg, melyek meghatározzák, hogy mit

8 (1993) PIQR Q30. Az ügyben a tűzoltó károsult hivatása gyakorlása közben - a metróban kitört tűzvész oltásakor - szenvedett el olyan sérüléseket, melyek ugyan fizikailag nem bizonyultak súlyosnak, azonban később poszttraumás stresszzavar kialakulásához vezettek. 
tekintenek megfelelő mértékü kártérítésnek az egyes esetkategóriákban, így ezzel viszonyítási alapot adnak az egyes ügyekben megitélhető kártérítési összegekre. A legsúlyosabb sérülés (súlyos agykárosodás vagy kvadriplégia - négy végtagi bénulás) esetére megítélhető összeget adják meg viszonyítási alapként, ami referenciául szolgál az egyéb sérülések mértékének megállapításához. Az egyes sérülésekhez rendelhető kártérítési összegek általában nincsenek összegszerüen meghatározva, hanem egy tartományon belül a bírák megítélésére van bízva a konkrét összeg megállapítása. ${ }^{9}$ A Judicial College (régebben Judicial Studies Board, melyet még 1979-ben alapítottak, s melynek fő feladata a bírák képzése) évente bocsát ki irányelveket arra vonatkozóan, hogy egyes esetekben milyen összegek ítélhetöek meg, a 2017-es irányelv szerint például egy négy végtagi bénultságot, vagy teljes vakságot, vagy süketséget okozó káresemény következtében a megítélhető általános kártérítés 322060 angol font (GBP) körüli összeg.

Az általános kártérítés mértékének meghatározása az elmúlt 25 évben sok vita tárgyát képezte. Még 1999-ben a legmagasabb megítélhető összeg 100000 GBP volt, azonban többször felmerült, hogy ezt az összeget emelni kellene. 2001-ben a Heli v. Rankin ügyben ${ }^{10}$ a Fellebbviteli Bíróság kimondta, hogy az összegeket emelni kell, azonban nem egységesen, hanem a sérülés mértékének megfelelően, így a legsúlyosabb esetekben az eddigi összegeknél egyharmaddal többet kell megítélni, míg a legkisebb sérülésnél - 10000 GBP és az alatt - nincs emelés.

Bár azt is elismerik, hogy nehéz egy személyi sérülés esetén a megfelelö nem vagyoni kártéritést összegszerüsíteni, azonban az emelést több érv is alátámasztja. Egyrészt a társadalom elvárása is efelé mutat (erre a riport egy 1900 résztvevőt számláló, egyes eseteket magába foglaló kérdőív segítségével kapott választ); másrészt a nem vagyoni károk sokszor az idő elteltével jelentősebbnek mutatkoznak, mint a kereset benyújtásakor; harmadrészt a károsultak várható élettartama is jelentősen megnövekedett az elmúlt évtizedekben. A Fellebbviteli Bíróság (Court of Appeal) a Simmons v. Castle ügyben ${ }^{11}$ mondta ki azt, hogy az általános kártérítés mértékét 2013. 04. 01-jétöl 10\%-kal emelni kell. Az emelést az eljáró bíró - Lord Woolf MR - azzal indokolta, hogy a bíróság kötelezettsége nemcsak az, hogy megállapítsa a kártérítési összegeket, hanem az is, hogy ezen összegeket naprakészen tartsa, így az emelést a megváltozott társadalmi viszonyok is indokolják. A bíróság azt is kimondta, hogy a bírák szerepe a kártérítési irányelveket figyelemmel kísérni, sőt meg is változtatni a kártérítési összegek mértékét, amennyiben azt szükségesnek látják.

Bár minden egyes eset egyedi, a bírák általában tiszteletben tartják az irányelvek által meghatározott összegeket. Ennek következményeként értékelhető, hogy Ang-

9 Karaponou, Vaia-Visscher, Louis: Towards a Better Assessment of Pain and Suffering Damages. Journal of European Tort law, 2010, 10.

10 (2001) QB 272. Az ügybeni károsult rendőrkutyák kiképzésével foglalkozott. A felperes részvételével zajló incidens során kisebb sérüléseket szenvedett és poszttraumás stresszzavar alakult ki nála, ami miatt korábbi munkáját nem tudta folytatni.

11 (2012) EWCA Civ 1039. Az ügyben a károsult motorkerékpárral közlekedett, mikor a károkozó által vezetett személygépjármű elsodorta, melynek következtében leesett a motorkerékpárról és személyi sérülést szenvedett. 
liában a kártérítési összegek általában alacsonyabbak, mint az USA-ban, ahol nem a bíró, hanem az esküdtszék határozza meg az összegeket. Ugyanakkor például a rágalmazásos, becsületsértéses ügyekben - ahol továbbra is az esküdtszék hatáskörébe tartozik a kártérítési összeg meghatározása - általában magasabb összegek kerülnek megítélésre. Az esküdtszék nem köteles megokolni döntését, és senki nem érdeklődhet arról, hogy mi történt az esküdtszék tanácskozásán. Általános vélekedés szerint az esküdtszék általában meg akarja büntetni a károkozót, ezért ítél meg magasabb összegű kártérítést. ${ }^{12}$ Ezen szubjektív tényező kiküszöbölése, illetve mérséklése vezette az angol Fellebbviteli Bíróságot, amikor irányelveket bocsátott ki az alkalmazható kártérítési összegekröl. Az irányelvek által meghatározott összegek tehát alapot nyújtanak a bíráknak a kártérítési összeg meghatározásakor, azonban természetesen az eset összes körülményeinek vizsgálata után dönt a bíró a kártérítési összegről.

A nem vagyoni kártérítés fogalmához legközelebb az általános kártérítés (general damages) áll, mely magában foglalja az elmúlt, jelenlegi és jövőbeni fájdalmat és szenvedést (pain and suffering), melyet a károsodás okozott - beleértve a pszichológiai jellegủ károkat is - és azon kellemetlenségeket, melyek magában foglalják az élet élvezetének elveszítését (loss of amenity). Mindezen jogcímeket összefoglalva az eljáró bíróság egy összeget állapít meg általános kártérítés címén.

A pain and suffering jogcímen megítélt kártérítés mindazon fájdalmat és szenvedést kárpótolja, mely a baleset következménye. A mérték megítéléséhez az eljáró bírónak tudnia kell, hogy pontosan mi történt, milyen hosszú ideig állt fennt a fájdalom. Ezen a jogcímen kell megtéríteni minden olyan jelenlegi és jövőbeni szenvedést, mely a balesettel összefüggésbe hozható, vagy annak következményeként keletkezett (pl. orvosi beavatkozás). Nem jár azonban kártérítés ezen a jogcímen, ha a károsult nincs eszméleténél, és nem érzékeli a fájdalmat, ${ }^{13}$ illetve ha a halál azonnal bekövetkezett. ${ }^{14}$

A loss of amenity fogalmát már egy kicsit nehezebb megfogalmazni. Ahogy Lord Reid mondta a West\&Son Ltd $v$. Shepard ügyben: ${ }^{15}$ „Két megközelítés létezik ezzel a kártéritési formával kapcsolatban. Az egyik, hogy a károsultat az elveszített végtagjáért vagy emésztési problémájáért kompenzáljuk. A másik, hogy az igazi veszteség nem a sérült fizikai sérülése, hanem azon lehetöségeknek az elveszítése, melyek szükségesek lennének ahhoz, hogy teljes és normális életet éljen, és amitöl most fizikai állapota öt megfosztja, és itt még a kis kellemetlenségeket is tolerálnunk kell."

12 Markesinis, Basil-Coester, Michael-Alpa, Guido-Ullstein, Augustus: Compensation for Personal Injury in English, German and Italian Law. Cambridge University Press, Cambridge, 2005, 17.

13 Wise v. Kaye (1962) 1 QB 638. Az ügyben a 20 év körüli károsult utasként részese volt egy közlekedési balesetnek, melyben olyan súlyos sérüléseket szenvedett, melynek következményeként a baleset időpontjától kezdve egészen az ítélethozatalig ( 3 és fél évvel későbbi időpont) eszméletlen volt.

14 Hicks v. Chief Constable of South Yorkshire Police (1992) 2 All ER 65. Az ügyben károsultként szereplő szülők két kiskorú gyermeke egy futballstadionba való bejutás során vesztette életét, amikor a stadionba bejutni kívánó tömeg a szük helyen annyira összezsúfolódott, hogy 95 ember halálos sérüléseket szenvedett. Az ügyben szereplő két kiskorú halálát az orvosi vélemény szerint azonnali fulladás okozta.

15 (1964) AC 326 at 341. Az ügyben szereplő károsultat egy teherautó ütötte el, mely során súlyos fejsérüléseket szenvedett, melynek következtében négyvégtag-bénulás alakult ki nála, valamint elvesztette beszédkészségét, és teljes körű ápolásra szorult. Állapotának javulására nem lehetett számítani. 
A loss of amenity jogcímen kompenzálható például a sportos életmód feladásának kényszere, valamelyik érzékszerv elveszítése, a szexuális életre való képesség elveszítése, házasságkötési esélyek csökkenése, nyaralás meghiúsulása.

A kártérítés megállapításánál mindenképpen fontos mérlegelni a körülményeket, nemcsak a baleset, hanem a sérült körülményeit (életkor, életvitel stb.). Így egy fitt, sportos egyén, aki a baleseti sérülései miatt nem képes korábbi életvitelének megfelelő életet élni, magasabb kártérítésre számíthat, mint egy idős, otthon ülő ember. Azonban ezen a jogcímen jár kártérítés akkor is, ha a sérült nincs tudatánál.

A pain and suffering és a loss of amenity közötti különbséget Lord Scarman fejtette ki a már említett Lim Poh Choo v. Camden and Islington Area Health Authority ügyben.$^{16}$ Eszerint a pain and suffering megítélése attól függ, hogy a sérült képes-e a fájdalom érzékelésére. A loss of amenity viszont a lehetőségek elveszítését kompenzálja, így nem függ attól, hogy a károsult azt érzékeli-e vagy sem.

Ezt a vélekedést 1998-ban a Law Commission riportjában ${ }^{17}$ is megerösítette, mikor kimondta, hogy a pain and suffering jogcímet mindig egyénenként, szubjektíven kell vizsgálni - azon keresztül, hogy a károsult mit érzékel a sérülésből - és nem objektíven. Tehát ha a károsult személy nincs tudatánál, nem jogosult pain and suffering jogcímen kártérítésre. A riportban a Commission elutasította azt az álláspontot, mely szerint a tudomány jelenlegi állása szerint nem lehetünk abban biztosak, hogy az öntudatlan vagy kómás sérültek mennyit érzékelnek a külvilágból, mivel azokat a károkat kell megtéríteni, melyek bizonyítható hátrányként jelentkeznek. Így annak a lehetősége, hogy a tudomány jobban elörehaladott lehetne ebben a kérdésben, és akkor annak nyomán olyan álláspont érvényesülne, hogy a tartósan öntudatlan károsultak valamilyen formában érzékelik a saját állapotukat, nem elegendő ahhoz, hogy ezen a jogcímen a kártérítési igény megálljon.

A loss of amenity tekintetében a riport a legnagyobb kihívást a kártérítés mértékének megállapításában látja. Mivel ezt a jogcímet - szemben a pain ans sufferinggel objektíven szükséges megállapítani, így egy tartósan öntudatlan, illetve agykárosult sérült az irányelvekben lefektetett legmagasabb mértékủ loss of amenityre jogosult. Természetesen egyéb körülmények értékelését sem lehet mellőzni, és csökkenteni lehet például a kártérítés mértékét, ha a sérült várható élettartama jelentősen megrövidült. ${ }^{18}$

\subsection{Pszichikai károk}

A Hinz v. Berry ügyben ${ }^{19}$ a bíróság azt mondta ki, hogy nem jár kártérítés egy személy elvesztése miatt érzett gyász következtében. Azonban meg kell különböztetni

16 (1980) AC 174.

17 The Law Commission: Damages for personal Injury: Non Pecuniary Loss. 1998, 6. http://www.lawcom.gov. uk/wp-content/uploads/2015/03/lc257_Damages_Personal_Injury_Non-pecuniary_Loss.pd (2014. 12. 01.).

18 The Law Commission: i. m., 9.

19 (1970) 2QB 40at 42. Az ügyben a károsult (a baleset idején állapotos asszony) férjével és négy saját, valamint négy nevelt gyermekével lakóautóval kirándulni indultak. Megálltak piknikezni, és az asszony egy gyermekével átment az úton, míg a férj a többi gyermekkel a lakóautóban maradt. Egy gépkocsi az úton nagy sebességgel közeledett, kidurrant a kereke, melynek következtében a személygépkocsi irányíthatatlanná 
a gyászt attól a súlyos, elhúzódó pszichés állapottól, melyet szakorvos állapít meg, például az úgynevezett poszttraumatikus stressz, mely egy közeli hozzátartozó vagy barát hirtelen, erőszakos halála miatt is kialakulhat. A pszichés sérelemnek tehát felismerhetőnek, diagnosztizálhatónak kell lennie, önmagában az aggódás, idegesség nem elegendő a kártérítés megítéléséhez. Illetve akkor is élhet igénnyel a károsult, ha bizonyítja, hogy a pszichikai károsodása olyan helyzetből fakad, amelyben a fizikai sérelem bekövetkezésének reális veszélye fennáll, és az ettől való félelem miatt alakult ki nála a pszichés állapot.

Az angol bíróságok azonban különbséget tesznek elsődleges és másodlagos áldozatok között a pszichikai károk tekintetében.

Elsődleges áldozatnak tekinthető, aki saját maga szenved pszichikai károsodást egy balesetben való részvétel során. A másodlagos áldozat pszichés károsodása annak a következménye, hogy látott vagy értesült egy olyan balesetröl, melyben mások károsodtak. Az elsődleges áldozatok tekintetében elfogadott tény, hogy amenynyiben fizikailag megsérültek, és így kártérítésben részesülnek, pszichikai károkra is igényt tarthatnak. A másodlagos áldozatok körében nem ilyen egyértelmű a helyzet. Valamely baleset szemtanúja szenvedhet pszichikai károsodást annak következtében, hogy látja mások halálát, illetve sérülését. Azonban az angol bíróságok csak olyanok tekintetében ismerik el ezt a fajta kárt, akik jelen voltak a balesetnél (és nem pedig hallomásból vagy akár televízióból értesültek arról). ${ }^{20}$

A pszichikai károsodás akkor is megállhat, ha nincs olyan hirtelen esemény, amely mintegy sokkot vált ki a másodlagos áldozatból, például akkor, ha a másodlagos áldozat ápolja a sérültet. A másodlagos és elsődleges áldozatok közötti kapcsolat lehet rokoni, baráti vagy akár munkakapcsolat is; nem a rokoni szál, hanem az érzelmi kötődés a fontos. De egy ügyben ${ }^{21}$ már 1925-ben is megítélt kártérítést a bíróság másodlagos áldozatnak azon az alapon, hogy valamilyen társadalmi indíttatásból empátiát érzett az elsődleges áldozat irányában - ebben az esetben egy gyermek baleseti sérülése és halála volt az ezt kiváltó ok. A másodlagos áldozatnak a kártérítés megítéléséhez azt kell bizonyítania, hogy általában nem abnormálisan hajlamos az ilyenfajta pszichés károsodásra; hogy a betegségét olyan sokkhatás váltotta ki, melynek tanúja volt; és hogy az elsődleges károsult és közötte közeli kapcsolat állt fennt.

vált, és belecsapódott az út mentén álló lakóautóba. A férj a baleset során életét vesztette, több gyermek megsérült.

20 Atkinson V. Seghal (2003) All ER (D) 641. Egy autóbaleset során a károsult lánya életét vesztette. Az anya később ért a helyszínre, és ott közölték vele a halálhírt, azonban a balesetet magát nem látta.

21 Hambrook v. Strokes Brothers (1925) 1KB. A károsult gyermekeit kísérte, éppen elbúcsúzott tölük, amikor egy, a domb tetején járó motorral hagyott teherautó elindult lefelé a lejtőn. Bár a gyermekek már látótávolságán kívül voltak, egy szemtanú azt közölte vele, hogy az elszabadult teherautó elütött egy gyermeket. A közlés következményeképpen olyan sokk érte az anyát, hogy később az a halálát okozta. Az esetben az anya férje volt jogosult kártérítésre mint másodlagos áldozat. 


\section{Személyi sérülés, felelősségbiztosítás, társadalombiztosítás és rehabilitáció}

$\mathrm{Az}$ angol Compensation Recovery Unit (CRU) statisztikái szerint a kétezres években nőtt a személyi sérüléses balesetekből eredő igények vonatkozásában támasztott kártérítési eljárások száma. ${ }^{22} \mathrm{~A}$ Pearson Commission riportjának idejében 250 000-re becsülték az éves személyi sérültes igényeket, tíz évvel később ez a szám már 340000 volt, és azóta is folyamatosan nő, a kétezres években már évi 700-750 000 igényről beszélhetünk. Ez a tendencia azonban nem az összes személyi sérüléses káreseményre jellemző. Például a foglalkoztatási felelősségi esetek nagymértékben csökkentek, aminek az oka az, hogy a gyártásban és nehéziparban nagyobb hangsúlyt helyeznek a balesetvédelemre, mint az elmúlt évtizedekben. A közlekedési balesetekből származó igényérvényesítések közben az 1970-es évek óta megnégyszereződtek. ${ }^{23}$ Ennek oka pedig nem a személyi sérüléses balesetek számának növekedése, hanem sokkal inkább a társadalmi tudatosság megerősödése. Míg a Pearson Commission még azt jegyezte fel, hogy sok sérült azért nem él kártérítési igénnyel, mert nem is ismeri ennek lehetőségét, napjainkban ez már egyáltalán nem állná meg a helyét. Mára teljesen elterjedt ismeret Angliában, hogy a közlekedési balesetek eredményeként ostorcsapásos sérülés (whiplash injury) ${ }^{24}$ alakulhat ki az autó vezetőjénél és utasainál. Így ma már a gépjármübalesetek $80 \%$ ánál nyújtanak be a fenti sérülés miatt igényt. Ezen sérülések különlegessége, hogy nehezen igazolható, illetve zárható ki bekövetkezésük, objektív jelei sokszor nincsenek, és általában a beteg saját elmondása alapján kerülnek rögzítésre az orvosi iratokban. Ezen sérüléseket rögzítő orvosi iratok rövid kivizsgáláson alapulnak, melyek sokszor a balesetet követően hónapokkal, évekkel később történnek meg.

Minél inkább elterjedt az ismeret, hogy hogyan lehet kártérítési igénnyel élni, annál inkább hajlamosak az emberek arra, hogy úgy értelmezzék az egyes eseményeket, hogy abból nekik kártérítés juthasson, valamint a kártérítési igényérvényesítés elfogadottá és rutinná válik. Így a társadalmi tudatosság lehetőséget és motivációt is biztosít az igények érvényesítésére. Kiszélesedett továbbá azon károsultak köre, akik kártérítési igénnyel élhetnek (például pszichikai károsodás annak következtében, hogy a károsult tanúja egy eseménynek). Ugyancsak oka lehet a megnövekedett igényeknek, hogy egyre több ügyvéd specializálja magát a személyi sérüléses igények érvényesítésére (és az 1980-as évek közepétől az ügyvédek már reklámozhatják is magukat), sokan alkalmazva a no-win no-fee elvet, tehát amennyiben a

22 Lewis Richard-Morris Annette-Oliphant Ken: Tort personal injury claims statistics: Is there a compensation culture in the United Kingdom? Torts Law Journal, 2006, 169.

23 LeWIS-Morris-Oliphant: i. m, 170.

24 A fej hirtelen előre- majd hátrabukása miatt bekövetkezett sérülés, mely során a nyak bizonyos szakaszai nagy lendülettel saját természetes ívükhöz képest ellentétes irányba mozdulnak el. A csontokban általában törés nem keletkezik, de a nyak kis ízületei megrándulnak, az izmokban, szalagokban apró szakadások következhetnek be, illetve a csigolyák közötti porckorongok sérülhetnek, akár sérv is kialakulhat. A maradványsérülések széles skálán mozognak, különösen nagy erőhatás esetén akár 100\%-os egészségkárosodást is eredményezhet, az esetek nagy részében azonban a panaszok nyaki fájdalom, fejfájás, szédülés, érzékenység, elalvási nehézségek, depresszió formájában jelentkeznek. 
kártérítési igény elutasításra kerül, a károsultnak nem kell megfizetni az ügyvédi díjat. Azonban az ellenfél költségeit ebben az esetben is meg kell térítse, ezért Angliában egyre elterjedtebb az olyan biztosítási forma, mely a káresemény bekövetkezte utáni jogi költségek megtérítésére szól. Így a peres eljárás pénzügyi kockázata is jelentősen lecsökkent. Mindezen tényezők a kártérítési igényérvényesítések számának növekedéséhez jelentösen hozzájárultak.

\subsection{A felelősségbiztositás és a kártérítési jog kapcsolata}

A biztosítások és a kártérítési jog kapcsolatát több oldalról is érdemes megvizsgálni, azonban nem kétséges, hogy maga a biztosítás mélységesen befolyásolja a kártérítési jog működését. Igaz, hogy a károkozók nagyon nagy része magánszemély, nagy többségében azonban rendelkeznek valamilyen felelősségbiztosítással, így a biztosító fog eljárni és kártérítést teljesíteni helyettük a kártérítési eljárás során, ezért az esetek nagy többségében a kártérítési perek alperesei a biztosító társaságok, nagyon ritkán magánszemélyek. Amikor a biztosító társaság lép a biztosított helyébe, ezzel a valódi károkozó elveszíti a kárügy feletti kontrollt, és így a további kártérítési eljárás, illetve per során a károkozó semmilyen szerepet nem játszik. A biztosítótársaság dönt a továbbiakban a kártérítés kérdéseiben, úgymint jogalap, összegszerüség, anélkül hogy a biztosítottat - azaz károkozót - bármilyen mértékben is bevonná az eljárásba, vagy akár annak hiányában is megállapíthatja a kártérítési felelősséget, hogy azt a károkozó elismerné. A biztosítóknak van a legnagyobb szerepük a kártérítési eljárás, illetve kártérítési per során, így a biztosítók épületeiben, és nem a bíróságokon, ügyvédi irodákban alakul leginkább a kártérítési joggyakorlat. Mivel a biztosítók dominálnak a kártérítési eljárásban, így szinte lehetetlen a kárügyeket a biztosító joggyakorlatától függetleníteni, ezért elmondhatjuk, hogy minden egyes kárügy érintett, akár eljut a bírósági szakaszba, akár nem. A biztosítók teljesítik a kártérítést a legegyszerübb kárügyektöl kezdve a legbonyolultabb kárügyekig, és ők döntik el, hogy a károsodás mely elemeit, milyen jogcímen fogadják el vagy utasítják el. Ök döntik el, mikor menjen egy kárügy bírói szakaszba, és hogy a bírósági eljárás során milyen taktikát alkalmazzanak. Objektív felelősségi esetekben a biztosítónak kell a peres eljárás költségeit is viselni, egyrészt azért, mert amennyiben a károsult kötelezettsége lenne a költségek viselése, akkor a károsultak egy részének nem érné meg a kárigények bírósági érvényesítése, mert esetleg a bírósági költségek meghaladnák a kártérítési összeget; másrészt ahhoz, hogy a biztosítótársaságok kártérítési eljárása a teljes kártérítés elvének megfeleljen, a kártérítésnek magában kell foglalnia a bírósági eljárás költségeit. ${ }^{25} \mathrm{~A}$ gyakorlatban a kártérítési eljárások döntő többsége a biztosító és a károsult peren kívüli megegyezésével zárul, és csak az esetek kis része jut el a bírósági szakaszba.

A személyi sérültes kártérítési eljárásokra is ugyanez igaz. A személyi sérültes kártérítések legnagyobb része üzemi baleset vagy gépjármübaleset következmé-

25 Arlen Jennifer: Tort Damages. In: Bouckaert, Boudewijn-De Geest, Gerrit (ed): Encyclopedia of Law and Economics. Edward Elgar, Cheltenham, 2000, 691. 
nye, és mivel mindkét esetben kötelező a felelősségbiztosítás, a személyi sérültes kártérítési eljárásokat is a biztosítótársaságok eljárása határozza meg legnagyobb részben. A biztosítói befolyás a kárrendezési eljárásra természetesen magában foglalja a kártérítés mértékére gyakorolt hatást is. A kártérítés mértékének meghatározásakor a bíróságok is figyelembe veszik, hogy egy biztosító az, aki a kártéritési összeget meg fogja téríteni, a megállapított kártérítési összegeket egy magánszemély a legtöbb esetben ki sem tudná fizetni. Egyes bírósági döntésekböl világosan kiderül, hogy a személyi sérültes kártérítési perekben eljáró bírák teljes tudatában vannak a biztosítás és kártérítési jog közötti szoros kapcsolatnak. Az angol bíróságok például több ügyben ${ }^{26}$ kimondták, hogy az egyes személyi sérüléses ügyekben megítélt magasabb kártérítési elemek vezethetnek ahhoz, hogy a biztosítótársaságok megemelik a biztosítási díjakat, ami az állampolgárok jelentős részére lesz így kihatással. Talán ennek is tudható be, hogy a személyi sérüléses kártérítési igények megítélésének alapvető elvei változatlanok maradtak az elmúlt 50-70 évben. Biztosítás nélkül szinte lehetetlen lenne annak a kártérítési elvnek megfelelni, hogy a károsultat olyan helyzetbe kell hozni, mintha a kár meg sem történt volna, föleg egy súlyos személyi sérüléssel járó káresemény következményei esetében, így elmondhatjuk, hogy biztosítás nélkül a kártérítési jog alapsajátosságai változnának meg.

Az angol jogirodalomban egyes kommentátorok ${ }^{27}$ a kötelező felelösségbiztosítást egyenesen a kártérítési jog mögött müködő „rejtett kézként” (hidden hand) írják le, vagyis a kötelező felelősségbiztosítás megléte egy kártérítési perben, illetve a jogalap és kártérítési összegek megállapításakor döntő szerepet játszik, még akkor is, ha esetleg az eljáró bíró nem tudatosan veszi azt figyelembe. Még a legvisszafogottabb kommentátorok is - mint például J. Stapleton - elismerik, hogy a biztosítás szerepe nyilvánvaló a kártérítési jog müködése mögött, ugyanakkor felhívják a figyelmet arra is, hogy óvatosan kell kezelni a kártérítési jog és a biztosítás kapcsolatát, hiszen a kártérítési jog alapvető elemei a kötelező felelősségbiztosítás elterjedésével sem változtak meg lényegesen, azok továbbra is a proof of fault elvén alapulnak. ${ }^{28}$ Azokban az időkben, mikor még az angol bíróságokon kártérítési esetekben is esküdtszék hozta a döntést a felelösség és a kártérítési összegek mértékében, az esküdteknek nem is lehetett tudomására hozni, hogy a károkozó rendelkezett-e felelősségbiztosítással, annak érdekében, hogy ez a tény ne befolyásolja az esküdtszéket a döntése meghozatalában.

A biztosítások közül elsősorban a felelösségbiztosítások szerepe a meghatározó, ahol a biztosító a biztosított helyett áll helyt a károsult felé, a vagyonbiztosítások a kártérítési eljárásokra nincsenek ilyen hatással, hiszen a vagyonbiztosításoknál a kártérítésnek nem feltétele a felelősség megállapítása. Szemben a felelősségbiztosítással, ahol - bár objektív felelősségi alapon - a felelősséget mindig vizsgálni kell, annak megállapítása a kártérítési eljárás elindításának első feltétele. A felelősségbiztosítás általában szükebb körü kockázatokra terjed ki, mint a vagyonbiztosítás, a felelösségbiztosítás alapján térítésnek általában akkor van lehetősége, ha a

\footnotetext{
26 Wells v. Wells (1999) AC 345,405 és Lim v. Camden Area Authority (1980) AC 174, 187.

27 WAGNER Gerhard (ed): Tort law and Liability Insurance. Springer, Wien, 2005, 63.

28 StAPLETON Jane: Tort, Insurance and Ideology. The Modern Law Review, 1995, 820.
} 
károkozó felelőssége megáll. Minél inkább elmozdulunk azonban az objektív felelősség irányába, annál közelebb kerülünk a vagyonbiztosításokhoz, hiszen minél objektívabb a felelösség, annál nagyobb körü azon kockázatok köre, melyek alapján a felelösség megállapítható.

A gyakorlatban jelentős különbség van a felelősségbiztosítási esetek körén belül is a dologi károk és a személyi sérüléses károk között, mivel az emberek igen kis százaléka köt olyan egészségbiztosítást, amit egy gépjármü esetén a vagyonbiztosításhoz lehetne hasonlítani, tehát egészségben bekövetkezett (saját hibás) károsodás esetére - bár az emberek egyik legnagyobb értéke az egészség és a munkaképesség megörzése. Ennek oka egyrészt a társadalombiztosítás müködésében rejlik, mely bizonyos mértékig védelmet nyújt ezen esetekben - igaz korlátozott mértékben -, és e fölött a mérték fölött csak a kártérítési jog nyújthat megfelelő kompenzációt. Ha a személyi sérülésekre kötött biztosítások, illetve keresetveszteség-biztosítások ugyanolyan elterjedtek lennének, mint a vagyonbiztosítások (pl. casco biztosítás), akkor a személyi sérültes kártérítési eljárások száma nagy valószínűség szerint jelentősen lecsökkenne, ${ }^{29}$ valamint a károsultak akkor is kártérítéshez juthatnának, ha nincs olyan személy, aki a károsodásért felelőssé tehető lenne.

A megfelelő kártérítési összegek megítélése elengedhetetlenül szükséges a kártérítési jog hatékony müködéséhez, bár azt is meg kell említeni, hogy nincs olyan szabály, mely minden esetre biztosítani tudná a megfelelő összeg meghatározását, tekintve a kártérítési esetek sokszínüségét. A megfelelő kártérítési összeg függ a sérülés mértékétől, a károkozó és a károsult közötti kapcsolat minőségétöl és a kockázat jellegétől (egyoldalú, kétoldalú vagy piaci kockázat), a felelősség természetététöl (veszélyes üzemi felelősségröl beszélhetünk-e vagy sem), hogy a felelősség egyéni vagy más helyetti, és még további tényezőktöl (költségek, bizonyítási problémák stb.). ${ }^{30}$

Dologi károk esetén a balesetek tradicionális közgazdasági modelljének elemzése szerint a megfelelő kártérítési összeg képes teljesen kompenzálni a károsultat a bekövetkezett kárért, így a károsult a károsodás piaci értékét kell, hogy kompenzációként megkapja. Azonban súlyos személyi sérülés vagy halálos károkozás esetén a fenti modell természetesen nem alkalmazható, már csak a sérülés természete miatt sem, hiszen az egészség, illetve élet nem helyettesíthető semmilyen más dologgal, illetve piaci értékét sem lehet meghatározni. Fenti káresetekben a kártérítési rendszer nem tudja betölteni a teljes kártérítés funkcióját, mivel az esetek többségében a károsultat nem lehet olyan helyzetbe hozni, mint amilyen helyzetben volt a baleset bekövetkezése előtt - a súlyos személyi sérüléses balesetek nagy részében ez a helyzet, nem is beszélve a halálos balesetekröl. ${ }^{31}$ További problémát jelent a nem vagyoni kártérítés szubjektív jellege, hiszen a kártérítés összegét csak egyedileg, a károsult körülményeit figyelembe véve lehet megállapítani; ezen károk mindig sze-

29 CANE, Peter: Atiyah's Accidents, Compensation and the Law. Cambridge University Press, Cambridge, 2006, 236.

176 30 ARLEN: i. $\mathrm{m}, 682$.

31 ARLEN: i. m, 699. 
mélyre szabottak, minden károsultat máshogy érintenek, ${ }^{32}$ és magukban foglalják mindazt a fájdalmat, szenvedést, aggodalmat, szorongást, félelmet, emocionális stresszt, az életminőség fizikai és pszichikai értelemben vett csökkenését, valamint az élet élvezetének elveszítését, melyek együtt járnak egy súlyos személyi sérüléssel. ${ }^{33}$

\subsubsection{Társadalombiztosítás és rehabilitáció}

A szociális ellátások rendszerét az Egyesült Királyságban az 1997-es Társadalombiztosítási törvény (Act LXXX of 1997 on the Eligibility for Social Security Benefits and Private Pensions and the Funding for These Services) szabályozza, mely 1997. október 6-tól hatályos, és attól függetlenül alkalmazandó, hogy a baleset mikor következett be, illetve a kártérítési eljárás vagy per mikor indult.

Azon szociális és egészségügyi ellátások pénzbeli értékét, melyek a balesetek következményei, az ellátást biztosító szervek követelhetik a károkozótól, illetve annak biztosítójától. Az Egyesült Királyságban ezen összegek érvényesítését egy erre a célra létrehozott szerv, a Compensation Recovery Unit végzi, mely a károkozótól, illetve annak biztosítójától hajtja be a károsult egészségügyi ellátásának költségét. Gépjármübalesetből eredő károsodás esetén a károsult díjmentesen jogosult egészségügyi ellátásra az állami egészségbiztosítás keretén belül. Az egészségbiztosító pedig kiszámlázza az egészségügyi ellátás költségét a kárért felelős gépjármü kötelező felelősségbiztosítójának, azonban az esetek többségében ez egy standard összeg, függetlenül az eljárás bonyolultságától, és több audit is felvetette már, hogy a kórházak nem fordulnak olyan gyakran a biztosítók felé megtérítésért, mint amilyen gyakran azt megtehetnék. ${ }^{34}$

A balesetben sérült károsultak rehabilitációja (csakúgy, mint a nyugat-európai államok többségében) elterjedt gyakorlat az Egyesült Királyságban. A rehabilitációs eljárást a komplex rehabilitáció részterületeire oszthatjuk fel, úgy mint orvosi, foglalkoztatási rehabilitáció, valamint szociális rehabilitáció és technikai segítség, mely felosztás a fogyatékossá lett ember életproblémáin és azok megoldása érdekében nyújtott szolgáltatásokon alapszik. A rehabilitációs folyamat egyes részeit nagyon sokáig különálló, egymásra épülő szintenként kezelte a gyakorlat és a szakirodalom is. Azonban a közelmúltban kialakult szemléletváltás eredményeként a rehabilitációs szolgáltatások már egy komplex folyamat részei, ahol az egyes területek egymásba illő és váltakozó súlypontú részfolyamatként írhatók le, melyek mintegy fogaskerékként illeszkednek egymásba, így fontossági sorrendet sem lehet köztük felállítani.

A rehabilitáció fogalma valamilyen fogyatékossággal rendelkezők esetén akkor használatos, amikor a társadalomba történő beilleszkedés valamilyen, rendszerint orvosilag meghatározható okból (pl. valamilyen egészségkárosodás miatt) megnehezül. A rehabilitáció hivatalos, világszerte elfogadott meghatározását a WHO tet-

\footnotetext{
32 Lindenbergh, Siewert D.-Van Kippersluis, Peter P. M.: Non pecuniary losses. In: Faure, Michael (ed): Tort Law and Economics. Cheltenham, Northampton, 2009, 221.

33 Karaponou-Visscher: i. m, 10.

34 Gobelet, Charles-Franchignoni, Franco: Vocational rehabilitation. Springer, France, 2006, 263.
} 
te közzé 1980-ban, mely szerint a rehabilitáció „olyan szervezett segítség, melyre egészségükben, testi, illetve szellemi épségükben tartósan vagy véglegesen károsodott emberek rászorulnak a társadalomba, a közösségbe történő visszailleszkedésük érdekében". ${ }^{35}$ Ugyanakkor az Egészségügyi Világszervezet ennél tovább is megy, mikor kimondja, hogy: „A rehabilitáció fogalmába beletartoznak azon összehangolt orvosi, szociális, szakképzési, oktatási és technikai intézkedések, melyek alkalmasak arra, hogy a sérült személy fizikai és társadalmi helyzetét javitsák, így a sérült képes legyen elérni állapotának maximális funkcionális javulását, és aktív részese legyen a társadalmi környezetének, valamint aktívan vehessen részt az élet bármely területén saját szabad választása szerint." ${ }^{36} \mathrm{~A}$ rehabilitáció célja, hogy biztosítsa az egészségkárosodást szenvedett személy szakmai és munkaképességét, valamint fejlessze és szinten tartsa a fizikai, mentális, szociális képességeket, ezzel létrehozva a komplex rehabilitációs folyamatot.

\subsubsection{Az orvosi rehabilitáció}

A komplex rehabilitáció részterületei közül az orvosi rehabilitáció célja, hogy az egészségi állapotukban károsodottakat - az egészségtudomány eszközeivel - meglévő képességeik fejlesztésével, illetve pótlásával segítse abban, hogy önállóságukat minél teljesebb mértékben visszanyerjék, és képessé váljanak a családba, munkahelyre, illetve más közösségbe való beilleszkedésre. A rehabilitációs medicina szerves része különösen a fizioterápia, a sportterápia, a pszichológiai ellátás, valamint a gyógyászati segédeszköz-ellátás és ezek használatának betanítása is. Az orvosi rehabilitáció célja a sérült személy állapotának megfelelő szintre hozatala, mely tevékenység az egyéntöl és helyzetétől függően sokféle lehet. Az orvosi rehabilitáció az a tevékenység, amelyet az orvostudomány a saját eszközeivel (diagnosztika, terápia, prevenció, gondozás) nyújt a megváltozott munkaképességü, valamint fogyatékos emberek számára. Az orvosi rehabilitáció tehát legnagyobb mértékben a testi struktúrák helyreállítására törekszik, amely már maga is komplex tevékenység, és a legtöbb esetben több szakember együttes döntésén, diagnózisán alapszik.

Az orvosi rehabilitáció akkor indokolt, ha a betegség vagy sérülés maradandó fogyatékosságot, megváltozott munkaképességet okozott és a fogyatékos vagy megváltozott munkaképességű személy aktivitása orvosi módszerekkel javítható, és így a társadalmi, közösségi életbe való visszavezetése elösegíthető.

Az orvosi költségek és rehabilitációs eljárások megtérítése esetén ugyanaz az angol alapfelfogás, mint a többi jogcím esetében, vagyis azokat az orvosi költségeket kell a kártérítési eljárás keretén belül megtéríteni, melyek a balesettel összefüggésben merültek fel, és szükségesek a sérült felépüléséhez, állapotának javulásához. A sérültnek kell bizonyítania - általában orvosi dokumentumokkal, orvosszakértői véleménnyel -, hogy a kérdéses orvosi kezelés szükséges. A George v. Stagecoach ${ }^{37}$

35 Word Health Organization, 1980.

36 WHO 668/1981 Technikai jelentés.

37 (2003) EWCH 2042. Az ügyben egy gyalogos hölgyet gázolt el egy emeletes busz, mely során a károsult a jobb láb lenyúzatásos sérülését szenvedte el. 
ügyben ugyanakkor azt is kimondta a bíróság, hogy a károsult akár alternatív terápiákat is igénybe vehet, ha bizonyítja, hogy azok hozzájárulnak állapota javulásához. A károsultak általában elsődlegesen az állami egészségügyi rendszer intézményeit veszik igénybe orvosi kezelésekhez, azonban amennyiben szükséges, magánintézmények szolgáltatásait is igénybe lehet venni. Sőt a Harris v. Brights Asphalt Contactors Ltd ügyben ${ }^{38}$ azt is kimondta a bíróság, hogy amennyiben a károsult bizonyítani tudja, hogy az igénybe vett magánkezelés szükséges volt, azt nem lehet azon az alapon kivonni a kártérítési tételek alól, hogy ha a károsult az állami egészségügyi rendszer kereteiben végezteti el a kezelést, akkor ez a költség nem merült volna fel. Ez különösen fontos a rehabilitációs kezelések szempontjából, hiszen azt is jelenti, hogy a károsult a rehabilitációs kezeléseket az állami, illetve a magánintézmények keretei között is igénybe veheti; természetesen a kezelés szükségességét továbbra is bizonyitania kell.

Annak eldöntésekor, hogy a súlyosan sérült, ápolásra szoruló károsultat otthonában vagy pedig egy magánkórházban, illetve magánintézményben kell-e ápolni, a szükségesség és a racionalitás a meghatározó. A bíróságok figyelembe veszik azt az életminőséget, melyet az ápolásra szoruló élvezhet, így megállhat annak szükségessége, hogy a sérültet egy magánintézményben vagy otthon ápolják.

\subsubsection{A szociális rehabilitáció és technikai segítség}

A szociális és pszichológiai kutatások egyértelműen bizonyították, hogy a fogyatékos emberek visszailleszkedését gátló tényezők nemcsak és nem elsősorban a sérült személyben találhatók meg, hanem sokszor a társadalom és a szociális környezet nehezíti meg az asszimilációt. Így a komplex rehabilitáció elengedhetetlen eleme a kitaszítással, szegregációval való szembeszállás. Az integráció maga is visszahat a közösségre, a társadalom maga is szocializálódik a fogyatékossággal történő együttélésre. ${ }^{39} \mathrm{~A}$ fogyatékos emberekkel szembeni diszkrimináció sokszor van negatív hatással a fogyatékos ember pszichés fejlődésére, és így magára a rehabilitációs folyamatra is. A társadalom kirekesztő hatása, elutasító magatartása nemcsak a fogyatékos ember szempontjából káros, hanem a közösség és a munkaadók szempontjából is.

A rehabilitációs folyamat célkitűzéseinek megvalósulásához elengedhetetlenül szükséges, hogy a szociális rehabilitáció is átszője a folyamatot, magát a szociális rehabilitációt nem lehet azonban élesen elválasztani a többi területtöl, hanem azokkal együttmüködve kell, hogy érvényesüljön. A szociális rehabilitáció a komplex rehabilitációban folyamatosan jelen lévő azon tevékenységek összessége, amelyek abba az irányba hatnak, hogy a megváltozott munkaképességü személyek szociális kompetenciáinak, egyéni szociális helyzetének, társadalmi pozíciójának javítása,

38 (1953) QB 617. Az ügyben a károsult munka közben leesett a tetőről, és súlyos sérüléseket szenvedett, a munkáltatóját perelte azzal az indokkal, hogy az nem biztosította számára a biztonságos munkakörnyezetet.

39 KöNCzEı György: A rehabilitáció és a fogyatékosság. In: Könczei György-Kullmann Lajos (szerk.): Bevezetés a komplex rehabilitációba (Szöveggyüjtemény). Eötvös Loránd Tudományegyetem, Bárczi Gusztáv Gyógypedagógiai kar, Budapest, 2009, 17. 
szinten tartása megvalósuljon. Másrészt, tágabb értelemben a szociális rehabilitáció a közvetlen és a tágabb környezet, a társadalom befogadó készségét, toleranciáját igyekszik növelni.

A károsultnak a rehabilitációs technikai segítség keretein belül joga van azon költségei megtérítésére, melyek a megváltozott egészségi állapota miatt a lakása átalakításakor merülnek fel, például lift beszerelése, ajtók kiszélesítése. A bírósági gyakorlat szerint, ha az átalakítás nagy valószínűséggel megemeli az ingatlan értékét, akkor ezt a kártérítés megállapításakor figyelembe kell venni, mivel az a károsult gazdagodását idézné elö, és ez ellentétes a kártérítés céljával. ${ }^{40} \mathrm{Azt}$ sem lehet ugyanakkor kizárni, hogy ezen átalakítások csökkentik az ingatlan értékét. Ebben az esetben a károsult kérheti az értékcsökkenés értékét. ${ }^{41} \mathrm{Az}$ is elöfordulhat, hogy a károsult sérülése következtében új ingatlan vásárlására kényszerül (például egy kerekesszékes károsulttól nem lehet elvárni, hogy egy lift nélküli társasház emeletén lakjon). llyen esetekben a bíróság figyelembe veszi a károsult jelenlegi ingatlanának értékét, melyet levon a jövőbeni ingatlan értékéböl, és így a károsult csak a különbözetre tarthat igényt.

A károsult igényt tarthat azon eszközök beszerzésére, fenntartására és cseréjére is, melyekre szintén megváltozott egészségi állapota miatt van szüksége. Legyen az egy orvosi segédeszköz vagy akár egy autó. Itt is a szükségesség és a racionalitás alapján dönt a bíróság a megítélhető összegröl.

\subsubsection{A foglalkoztatási rehabilitáció}

A foglalkoztatási rehabilitáció célja a sérült, megváltozott munkaképességü ember számára a megfelelő munka megtalálása, megőrzése és az elömenetel elősegítése. Célja továbbá, hogy megteremtse a megváltozott munkaképességű személyek munkaerőpiaci integrációját elősegítő minimumfeltételeket, hogy az érintettek alkalmassá válhassanak a minél teljesebb értékủ foglalkoztatásra. Annak elérésére törekszik a foglalkoztatási rehabilitáció egyrészt, hogy a sérültek érdekeltek legyenek a munkavállalásban, másfelöl a munkáltatók is befogadóvá váljanak a fogyatékos emberek iránt.

A foglalkoztatási rehabilitáció alapja a megváltozott munkaképességú személy profiljának kialakítása, annak meghatározása, hogy melyek a személy adottságai, szaktudása, tapasztalata, a munkavállalást akadályozó tényezők, közlekedési lehetőségek. Ennek meghatározása egyfajta értékelési folyamat, melyben az egyén életútját, önmagáról alkotott képét és a vizsgálatok eredményét összevetik, és a vizsgálatot végző és a sérült közösen megállapítják, hogy jelen állapotában alkalmas-e, s ha igen, milyen munka végzésére, illetve hogy mely tényezők nehezítik meg, akadályozzák az elhelyezkedését, vagy éppen segítik elő azt.

40 Markesinis-Coester-Alp-Ullstein: i. m, 134.

41 Brown v. Merton, Sutton and Wandsworth Health Authority (1982) 1ALL ER 650. A tényállás szerint a károsult gyermeknél a kórházi tartózkodása során szívelégtelenség és légzési elégtelenség lépett fel. Bár az orvost riasztották, azonban nem jelent meg, és ennek következményeként a gyermek súlyos agykárosodást szenvedett. 
A foglalkoztatási rehabilitációt Angliában nagyrészt állami szervek finanszírozzák és teljesítik, illetve néhány nonprofit cég is végez ilyen tevékenységet. A sérült személy vagy a háziorvoson keresztül, vagy a munkaügyi központon keresztül tud foglalkoztatási rehabilitációs ellátást igényelni, amelyet követően rokkantsági foglalkoztatási tanácsadó (Disability Employment Advisor) fogja meghallgatni. A tanácsadó egy teljes körủ felméréssel kezdi meg a sérülttel való foglalkozást, mely magában foglal pszichológiai és gyakorlati teszteket is, illetve arra törekszik, hogy megállapítsa, a sérültnek milyen segítségre van szüksége ahhoz, hogy a munka világába vissza tudjon illeszkedni. Ennek érdekében segítséget nyújt különböző juttatások igénylésében (például munkába járási hozzájárulás), illetve ha a sérült személy nem alkalmas vagy nem képes korábbi munkakörébe visszahelyezkedni, akkor segít egy úgynevezett Alternatively Work Preparation Scheme megfogalmazásában, és ennek keretében a sérült részt vehet például átképzésen, illetve segít más munkáltatónál történő elhelyezkedésben.

Az állami segítség mellett nonprofit szervek is nyújtanak foglalkoztatási rehabilitációs szolgáltatást, és a megváltozott munkaképességűek számára széles körű segítséget nyújtanak például önéletrajzírásban, állásinterjúra való felkészítésben. Azon megváltozott munkaképességű munkavállalók számára, akik állapotuk miatt folyamatos támogatásra, segítségre szorulnak, az államilag támogatott WORKSTEP program nyújt segítséget, ami az elmúlt időszakban nagyjából 25000 munkavállalót érintett. ${ }^{42}$

A személyi sérüléssel foglalkozó ügyvédek szövetsége (The Association of Personal Injury Lawyers - APIL) is kiadott egy állásfoglalást az angol nemzeti iroda részére ${ }^{43}$ mely szerint a rehabilitációs eljárásnak minden munkáltatónál elérhetővé kell válnia, ugyanúgy, mint a biztonsági elő́rásoknak. Azon is dolgoznak, hogy a rehabilitációs szolgáltatók (egészségügy, munkáltatók) részvételével elöállítsanak egy rehabilitációs best practice-t, mely célul tűzi ki a szolgáltatók szorosabb együttmüködését. Véleményük szerint a rehabilitációs eljárások szük keresztmetszete a szolgáltatásokhoz való hozzáférés nehézsége és a minőségi és komplex rehabilitáció hiánya, ezért további vizsgálat szükséges a rehabilitációs lehetőségek és azok legjobb kihasználásának feltérképezése érdekében. A kutatás célja, hogy bebizonyítsák azt, hogy egy munkáltató, illetve biztosítótársaság szempontjából mindenképp elönyös - akár pénzügyileg is -, hogy a sérült személy rehabilitációját támogassák, mivel a komplex rehabilitáció sikeres megvalósítása esetén az ebből származó elönyök messze meghaladják a rehabilitáció költségeit. Szerintük a sikeres folyamat megalkotása érdekében létre kellene hozni egy olyan független szervezetet, mely a rehabilitáció összes szereplőjét összehozza.

A rokkantsági ellátásban részesülő sérültek nagyobb része egy éven belül visszatér a munka világába, azonban a gyakorlat azt mutatja, hogy akik egy éven belül nem válnak foglalkoztatottá, azon sérülteknek csak 20 százaléka fog tudni a későbbiek

42 Gobelet-Franchignoni: i. m., 270.

43 Association of British Insurers: Getting back to work - a rehabilitation discussion paper, Submission of the association of personal injury lawyers, http://www.abi.org.uk/Display/File/213/Getting_Back_to_Work_130602. pdf, (2017. 02. 14.). 
során elhelyezkedni. ${ }^{44}$ Ezért a rehabilitációs folyamat során Angliában jelentős forrásokat fordítanak arra, hogy megelőzzék a hosszú távú betegszabadságot, illetve minél jobban lecsökkentsék azok számát, akik egy évet meghaladóan részesülnek fogyatékossági ellátásban. A munka világába való visszahelyezkedés sokszor azért is lehet problémás, mert a sérült fél attól, hogy ha elvállal egy munkát, amit később nem fog tudni az állapota miatt elvégezni, akkor a fogyatékossági ellátástól is elesik. Ezt kiküszöbölendő néhány munkáltatónál már az a lehetőség is elérhető, hogy a munkavállaló bizonyos átmeneti időszakra fenntarthatja a fogyatékossági ellátását is. Ha az átmeneti időszak (általában 13 hét) sikeresen telt el, akkor megszünik a fogyatékossági ellátás. A Department of Work and Pension felmérése ${ }^{45}$ szerint nagyjából évente 3000 munkavállalón segítenek ilyen formában.

A Department of Work and Pension egy minisztériumi szerv, melynek többek között feladata a szociális ellátások szabályozása. Ez az állami szerv foglalkozik a foglalkoztatási rehabilitációval is, melynek keretein belül több programot is menedzselnek munkavállalói és munkáltatói oldalon is. Felülvizsgálták a fogyatékossági eljárásokra való jogosultságot, valamint arra ösztönzik a munkáltatókat, hogy fordítsanak nagyobb figyelmet a munkából kiesőkre, és próbálják meg őket minél hamarabb visszaterelni a munkahelyre, még mielőtt a hosszú távú betegállomány megszokottá válna. Ez az állami szerv a komplex rehabilitáció megvalósítása érdekében együttmüködik az egészségbiztosítási szervvel (National Health Services - NHS); több program keretében segítik a fogyatékos személyeket az egészségügyi és foglalkoztatási rehabilitáció összehangolásának keretein belül. Szintén a foglalkoztatási rehabilitációt segíti elő a munkáltatóknál müködő Health Scheme nevezetü program, melynek célja a hosszabb ideig vagy az átlagnál többször betegállományban lévő munkavállalók figyelemmel kísérése, és a hosszas távollét okának feltérképezése, megszüntetése.

\section{Zárógondolat}

Összefoglalva elmondható, hogy a common law alapokon nyugvó, a kontinentális jogrendszerek kártérítési fogalmaitól - különösen a nem vagyoni károk tekintetében - eltérő szabályozás a sérült személyek vonatkozásában a gyakorlat szempontjából bár eltéréseket mutat, azonban jelentős hasonlóságokat is fel lehet lelni. A kontinentális jogrendszerektől idegen a nem vagyoni kártérítés megbontása (pain and suffering és loss of amenity), valamint a nem vagyoni kártérítés negatív megközelítéssel való meghatározása, azonban az angol jogrendszer is a teljes kártérítés elvén nyugszik, és így megtéríteni rendeli a sérüléssel okozati összefüggésben keletkezett vagyoni és nem vagyoni károkat. A sérültek számára a kártérítési eljárásban biztosított rehabilitációs folyamat komplex, a foglalkoztatási rehabilitációban az állami szerveken és nonprofit szervezeteken kívül jelentős szerep hárul a munkáltatókra. Elmondható, hogy a rehabilitáció terén az angol joggyakorlat messze meghaladja a

44 Gobelet-Franchignoni: i. m., 265.

45 Department of Work and Pension: Pathways to work 2002. 
magyar rehabilitációs lehetőségeket és eljárásokat, azonban a rehabilitáció jelentösége és potenciálja Angliában is elmarad az optimálistól, és sajnos a sérült, illetve fogyatékos emberek jelentős része nem vesz részt elöre megtervezett, célorientált komplex rehabilitációs folyamatban. Ennek okaként fel lehet hozni, hogy - csakúgy, mint Magyarországon - azon egészségügyi szakemberek, akik a rehabilitációs folyamatot el tudnák kezdeni, inkább a sérültek egészségi állapotára koncentrálnak, és nem - vagy kevéssé - veszik figyelembe a rehabilitáció többi területét érintő kérdéseket.

\begin{abstract}
The article analyzes the specialties of the English legal system with a focus on the legal regulation and court practice of tort law, and especially the non material indemnification and rehabilitation of the bodily injured. The study starts with the description of the main characteristics of the tort law, the definition and jurisprudence of non material damages, like pain and suffering and loss of amenity and psychological damages are also reviewed in detail with respective court cases. The study also gives an analysis of the connection between tort law and insurance law, how one effects the other. Nowadays the indemnification process of the bodily injured cannot be full without rehabilitation. Like in most of the Western European countries, in the United Kingdom the rehabilitation process is a complex and centrally managed procedure with the help of state institutions and programs.
\end{abstract}

